\title{
ANALISIS PENGARUH INDEKS PEMBANGUNAN MANUSIA DAN KEMISKINAN TERHADAP PERTUMBUHAN EKONOMI KABUPATEN/KOTA DI PROVINSI KEPULAUAN BANGKA BELITUNG TAHUN 2010-2017
}

\author{
Yovita Sari $^{1 *}$, Aja Nasrun ${ }^{2}$, Aning Kesuma Putri ${ }^{1}$ \\ ${ }^{1}$ Fakultas Ekonomi Universita Bangka Belitung \\ ${ }^{2}$ Badan Pusat Statistik Provinsi Kepulauan Bangka Belitung \\ ${ }^{1}$ Fakultas Ekonomi Universitas Bangka Belitung \\ * Email: yovita_sari@yahoo.com
}

\begin{abstract}
ABSTRAK: Pertumbuhan ekonomi merupakan salah satu indikator yang paling penting dan sering digunakan dalam menentukan keberhasilan suatu pembangunan daerah ataupun negara. Faktor pendukung lainnya dalam keberhasilan pembangunan suatu daerah dapat dilihat dari Indeks Pembangunan Manusia yang merata serta jumlah penduduk miskin yang rendah sehingga suatu daerah dapat dikategorikan daerah yang sejahtera. Penelitian ini di beri judul Analisis Pengaruh Indeks Pembangunan Manusia dan Kemiskinan Terhadap Pertumbuhan Ekonomi Kabupaten /Kota di Provinsi Kepulauan Bangka Belitung Tahun 2010-2017. Tujuan dari penelitian ini adalah untuk mengetahui dan menganalisis bagaimana pengaruh Indeks Pembangunan Manusia dan Kemiskinan terhadap Pertumbuhan Ekonomi Kabupaten/Kota di Peovinsi Kepulauan Bangka Belitung rentang tahun 2010 sampai dengan 2017. Data yang digunakan dalam penelitian ini adalah data sekunder dengan metode analisis yang digunakan adalah Regresi Data Panel dengan metode Fixed Effect Model. Hasil penelitian ini menunjukkan bahwa kedua variabel yaitu Indeks Pembangunan Manusia dan Kemiskinan memiliki pengaruh negatif signifikan terhadap Pertumbuhan Ekonomi Kabupaten/Kota di Provinsi Kepulauan Bangka Belitung tahun 2010-2017.
\end{abstract}

Kata Kunci: Indeks Pembangunan Manusia (IPM); Kemiskinan; Pertumbuhan Ekonomi; Regresi Data Panel

\section{PENDAHULUAN}

Pertumbuhan ekonomi adalah hal yang selalu diprioritaskan sebab adanya pertumbuhan ekonomi mengindikasikan adanya pertambahan pendapatan perkapita.Hal ini dikarenakan pertumbuhan ekonomi memungkinkan terjadinya pembangunan ekonomi di banyak bidang. Teori Kuznets, pertumbuhan ekonomi adalah kenaikan jangka panjang dalam kemampuan suatu negara untuk menyediakan semakin banyak jenis barang-barang ekonomi kepada pendudunya, kemampuan ini tumbuh sesuai dengan kemajuan teknologi, dan penyesuaian kelembagaan dan ideologis yang diperlukannya (Jingan, 2010). Pembangunan ekonomi yang stabil sangat diharapkan oleh negara yang sedang membangun seperti Indonesia karena dapat mengatasi masalah kemiskinan, pengangguran, buta huruf meningkatkan kesejahteraan masyarakat dan memberi perhatian lebih di bidang kesehatan dan pendidikan. Dengan kata lain negara yang mengalami pertumbuhan ekonomi yang tinggi maka ia akan mampu memberikan efek 
yang tinggi terhadap bidang-bidang yang lain sebab ketika suatu negara mengalami pertumbuhan ekonomi maka pendapatan nasional suatu negara akan naik sehingga bisa dialokasikan untuk pembiayaan pembangunan infrastruktur perekonomian. Oleh sebab itu pertumbuhan ekonomi menjadi prioritas utama suatu negara guna mensejahterakan penduduknya (Masriah, 2011).

Pertumbuhan ekonomi merupakan perkembangan kegiatan dalam perekonomian yang menyebabkan barang dan jasa yang diproduksikan dalam masyarakat bertambah. Pertumbuhan ekonomi merupakan kenaikan PDB atau PNB rill. Sejak lama ahli-ahli ekonomi telah menganalisis faktor-faktor penting yang mempengaruhi pertumbuhan ekonomi. Berdasarkan kepada pertumbuhan ekonomi yang berlaku di berbagai negara dapat disimpulkan bahwa faktor utama yang mempengaruhi pertumbuhan dan pembangunan suatu negara adalah kekayaan sumber alam dan tanahnya, jumlah dan mutu tenaga kerja, barang-barang modal yang tersedia, tingkat teknologi yang digunakan dan sistem sosial dan sikap masyarakat (Sukirno 2011). Pertumbuhan ekonomi merupakan suatu kenaikan pendapatan nasional GDP atau GNP tanpa memandang apakah ada perubahan struktur ekonomi yang terjadi di suatu negara (Badrudin, 2012). Pertumbuhan ekonomi sebagai sebuah proses peningkatan output dari waktu ke waktu menjadi indikator penting untuk mengukur keberhasilan pembangunan suatu negara (Maharani dan Sri, 2014).

Pemerintah Indonesia menyadari bahwa pembangunan nasional adalah salah satu upaya untuk mencapai tujuan masyarakat adil dan makmur. Sejalan dengan tujuan tersebut, berbagai kegiatan pembangunan telah diarahkan kepada pembangunan daerah khususnya daerah yang relatif mempunyai tingkat kemiskinan yang terus naik dari tahun ke tahun. Pembangunan daerah dilakukan secara terpadu dan berkesinambungan sesuai prioritas dan kebutuhan masing-masing daerah dengan akar dan sasaran pembangunan nasional yang telah ditetapkan melalui pembangunan jangka panjang dan jangka pendek. Oleh karena itu, salah satu indikator utama keberhasilan pembangunan nasional adalah laju penurunan jumlah penduduk miskin. Efektifitas dalam menurunkan jumlah penduduk miskin merupakan pertumbuhan utama dalam memilih strategi pembangunan.Hal ini berarti salah satu kriteria utama pemilihan sektor titik berat atau sektor andalan pembangunan nasional adalah efektifitas dalam penurunan jumlah penduduk miskin (Wijayanto, 2010).

Pertumbuhan Ekonomi yang baik dapat dilihat dari kriteria beberapa indikator pendukungnya seperti Indeks Pembangunan Manusia yang sudah membaik dan merata serta jumlah penduduk miskin yang menurun karena pembangunan ekonomi sudah merata. Adapaun Indeks Pembangunan Manusia merupakan ukuran untuk melihat dampak kinerja pembangunan wilayah yang mempunyai dimensi yang sangat luas, karena memperlihatkan kualitas penduduk suatu wilayah dalam hal harapan hidup, pendidikan dan standar hidup layak (Melliana dan Zain, 2013). Sedangkan menurut Badan Pusat Statistik, kemiskinan dipandang sebagai ketidakmampuan dari sisi ekonomi untuk memenuhi kebutuhan dasar makanan dan bukan makanan yang diukur dari sisi pengeluaran.Jadi penduduk miskin adalah penduduk yang memiliki rata-rata pengeluaran perkapita perbulan dibawah garis kemiskinan (BPS, 2015). Proses pembangunan memerlukan pendapatan nasional yang tinggi dan pertumbuhan ekonomi yang cepat. Di banyak negara syarat utama bagi terciptanya penurunan kemiskinan adalah pertumbuhan ekonomi. Meningkatnya pertumbuhan ekonomi memang tidak cukup untuk mengentaskan kemiskinan, namun menjadi sesuatu yang dibutuhkan.Kenyataan ini berarti bahwa pertumbuhan ekonomi yang tinggi menjadi tidak berarti bagi penurunan 
masyarakat miskin jika tidak diiringi dengan pemerataan pendapatan (Wongdesmiwati, 2009).

Pertumbuhan Ekonomi Provinsi Kepulauan Bangka Belitung dari tahun 2010 sampai dengan 2017 mengalami pertumbuhan yang signifikan. Beberapa indikator seperti indeks pembangunan manusia danpersentase penduduk miskindapat mempengaruhi PDRB yang berdampak pada pertumbuhan ekonomi daerahdi Provinsi Kepulauan Bangka Belitung.Laju Pertumbuhan PDRB Kabupaten/Kota di Provinsi Kepulauan Bangka Belitung terdapat pada gambar 1 :

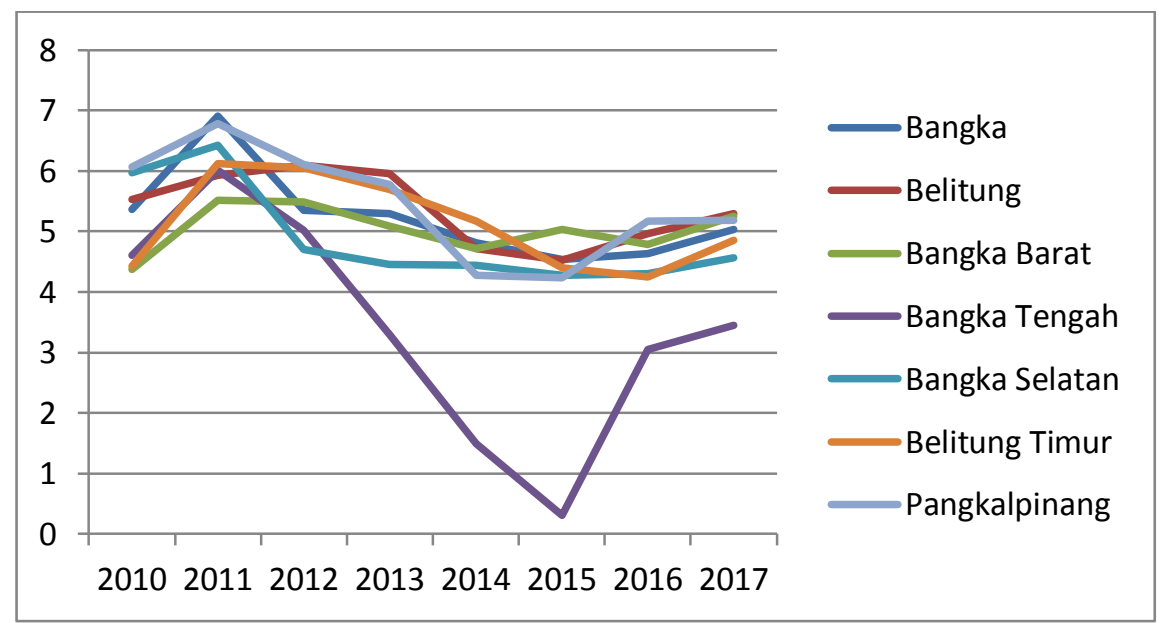

Gambar 1. Laju pertumbuhan PDRB Kabupaten/Kota di Provinsi Kepulauan Bangka Belitung Tahun 2010-2017

Sumber : Data diolah dari BPS Provinsi Kepulauan Bangka Belitung Dalam Angka Tahun 2010-2017 (2019)

Gambar 1 menunjukkan bahwa Bangka Tengah mengalami penurunan pertumbuhan PDRB terendah pada tahun 2015 sebesar 0,31 persen diantara Kabupaten/Kota yang lainnya, karena berhenti beroperasinya perusahaan swasta peleburan timah yaitu PT KOBATIN. Laju pertumbuhan PDRB tertinggi berada di Kabupaten Bangka sebesar 6,91 persen, karena ada lokasi spasial selain faktor manusia dan karakteristik sistem alam (De Moraes, 2015).

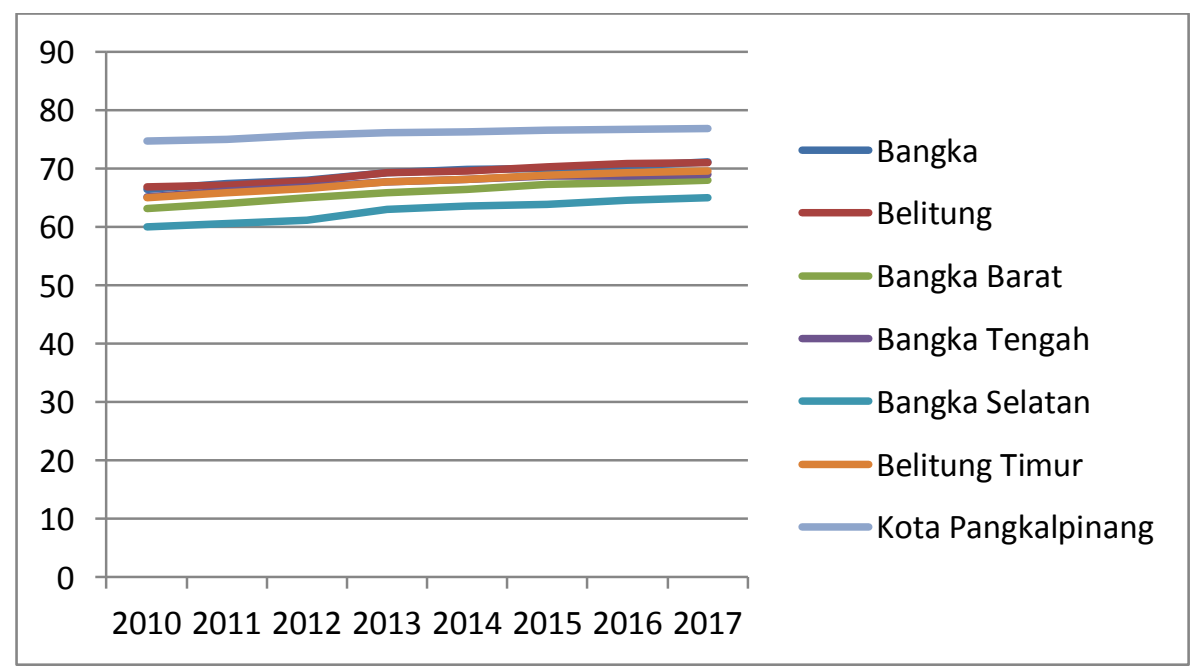

Gambar 2. Indeks Pembangunan Manusia Kabupaten/Kota di Provinsi Kepulauan Bangka Belitung tahun 2010-2017

Sumber : Data diolah dari BPS Provinsi Kepulauan Bangka Belitung Dalam Angka tahun 2010-2017 (2019) 
Pada gambar 2 persentase indeks pembangunan manusia terendah sepanjang tahun 2010 sampai dengan 2017 diperoleh Kabupaten Bangka Selatan kurang lebih 60 persen dikarenakan kurang meratanya pembangunan yang terhambat oleh beberapa faktor seperti sarana dan prasana tranportasi, jarak serta keadaan wilayah. Untuk indeks pembangunan manusia tertinggi berada di Kota Pangkalpinang sebesar 80 persen dikarenakan pembangunan sudah mulai merata di daerah Kota Pangkalpinang seperti sarana dan prasana yang sudah memadai, merupakan pusat kota sehingga pembangunan lebih diperhatikan. Adanya pertumbuhan ekonomi yang tinggi dan berkelanjutan dapat dipicu oleh peran sumber daya manusia yang berkualitas. Dengan aspek pendukungnya seperti standart hidup layak, investasi bidang pendidikan dan kesehatan yang merupakan sumber pembangunan Sumber Daya Manusia.

Jika dilihat dalam perkembangan persentase penduduk miskin di Provinsi Kepulauan Bangka Belitung, Bangka Barat merupakan Kabupateen yang memiliki penduduk miskin terbanyak di bandingkan Kabupaten lainnya. Persentase tersebut terdapat pada gambar 3.

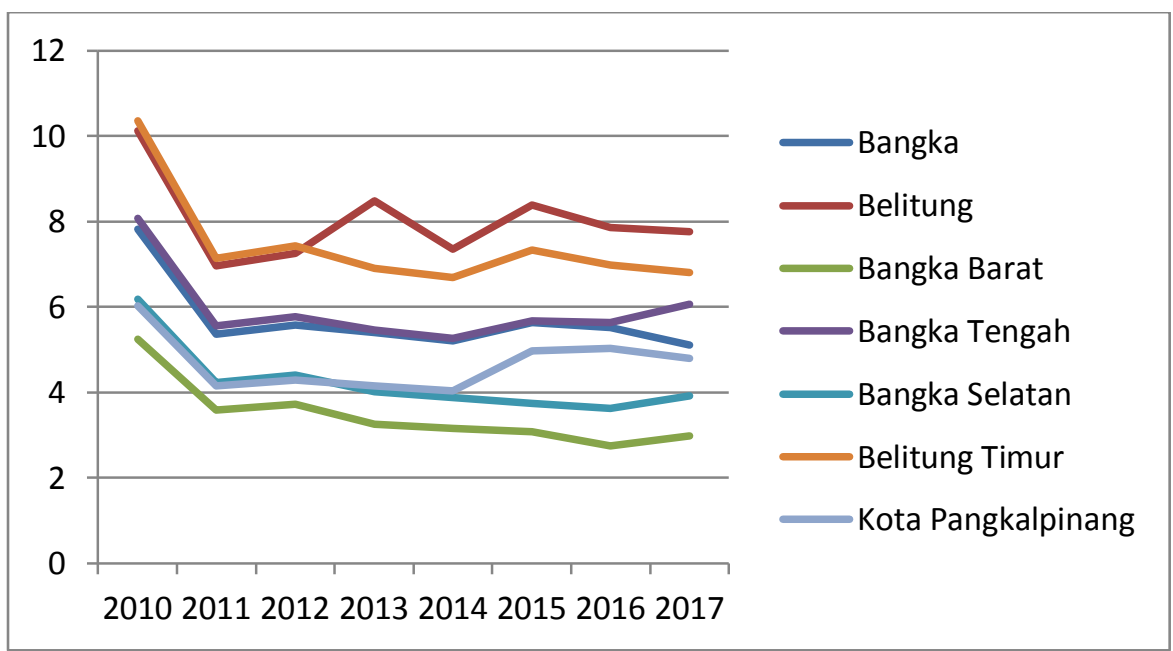

Gambar 3. Persentase penduduk miskin Kabupaten/Kota di Provinsi Kepulauan Bangka Belitung tahun 2010-2017

Sumber : Data diolah dari BPS Provinsi Kepulauan Bangka Belitung Dalam Angka tahun 2010-2017 (2019)

Gambar 3 menunjukkan bahwa persentase penduduk miskin terendah berada di Kabupaten Bangka Barat menyentuh angka 5,25 persen dibandingkan dengan Kabupaten Belitung Timur dengan persentase sebesar 10,36 persen yang merupakan persentase tertinggi ditahun 2010. Dan pada tahun 2017 Kabupaten Belitung merupakan yang paling tinggi dengan persentase sebesar 7,77 persen dibandingkan dengan Kabupaten Bangka Barat sebesar 2,98 persen yang merupakan persentase terendah di tahun tersebut. Terdapat beberapa faktor yang mempengaruhi jumlah persentase penduduk miskin yang berangsur menurun salah satunya ialah sudah meluasnya lapangan pekerjaan yang mulai merambah ke daerah pelosok-pelosok sehingga pendapatan yang didapat mulai meningkat.

Berdasarkan latar belakang, maka dapat diambil rumusan masalah dalam penelitian ini yaitu menganalisa pengaruh indeks pembangunan manusia dan kemiskinan terhadap pertumbuhan ekonomi Kabupaten/Kota di Provinsi Kepulauan Bangka Belitung tahun 2010-2017. Tujuan dari penelitian ini yaitu untuk menganalisa pengaruh indeks pembangunan manusia dan kemiskinan terhadap pertumbuhan ekonomi Kabupaten/Kota di Provinsi Kepulauan Bangka Belitung tahun 2010-2017. 


\section{TINJAUAN PUSTAKA}

\subsection{Pertumbuhan Ekonomi}

Pertumbuhan ekonomi adalah peningkatan output masyarakat yang disebabkan oleh semakin banyaknya jumlah faktor produksi yang digunakan dalam proses produksi, tanpa adanya perubahan "teknologi" produksi itu sendiri, misalnya kenaikan output yang disebabkan oleh pertumbuhan stok modal ataupun penambahan faktor-faktor produksi tanpa adanya perubahan pada teknologi produksi yang lama (Arsyad, 2010).

Pertumbuhan ekonomi merupakan perkembangan kegiatan dalam perekonomian yang menyebabkan barang dan jasa yang diproduksikan dalam masyarakat bertambah. Pertumbuhan ekonomi merupakan kenaikan PDB atau PNB rill.Sejak lama ahli-ahli ekonomi telah menganalisis faktor-faktor penting yang mempengaruhi pertumbuhan ekonomi. Berdasarkan kepada pertumbuhan ekonomi yang berlaku di berbagai negara dapat disimpulkan bahwa faktor utama yang mempengaruhi pertumbuhan dan pembangunan suatu negara adalah kekayaan sumber alam dan tanahnya, jumlah dan mutu tenaga kerja, barang-barang modal yang tersedia, tingkat teknologi yang digunakan dan sistem sosial dan sikap masyarakat (Sukirno 2011). Pertumbuhan ekonomi merupakan suatu kenaikan pendapatan nasional GDP atau GNP tanpa memandang apakah ada perubahan struktur ekonomi yang terjadi di suatu negara (Badrudin, 2012).

Pertumbuhan ekonomi adalah perkembangan kegiatan dalam perekonomian yang menyebabkan barang dan jasa yang diproduksi dalam masyarakat bertambah dan kemakmuran masyarakat meningkat dalam jangka panjang (Untoro, 2010). Indikator yang digunakan untuk mengetahui pertumbuhan ekonomi suatu negara adalah tingkat Produksi Domestik Bruto (PDB). Beberapa alasan digunakannya PDB (bukan PNB) sebagai indikator pengukuran pertumbuhan ekonomi,yaitu (Arifin \& Gina 2009) :

1. PDB dihitung berdasarkan jumlah nilai tambah (value added) yang dihasilkan seluruh aktivitas produksi di dalam perekonomian. Hal ini menyebabkan peningkatan PDB mencerminkan peningkatan balas jasa kepada faktor produksi yang digunakan dalam proses produksi.

2. PDB dihitung atas dasar konsep siklus aliran (circulair flow concept) yaitu perhitungan PDB mencakup nilai produk yang dihasilkan pada suatu periode tertentu. Perhitungan ini tidak mencangkup perhitungan pada periode sebelumnya. Pemanfaatan konsep aliran dalam menghitung PDB memungkinkan seseorang untuk membandingkan jumlah output pada tahun ini dengan tahun sebelumnya.

3. Batas wilayah perhitungan PDB adalah Negara (perekonomian domestik). Hal ini memungkinkan untuk mengukur sampai sejauh mana kebijakan ekonomi yang diterapkan pemerintah maupun mendorong aktivitas perekonomian domestik.

\subsection{Indeks Pembangunan Manusia}

Indeks Pembangunan Manusia merupakan ukuran untuk melihat dampak kinerja pembangunan wilayah yang mempunyai dimensi yang sangat luas, karena memperlihatkan kualitas penduduk suatu wilayah dalam hal harapan hidup, pendidikan dan standar hidup layak (Melliana dan Zain, 2013).

Secara ringkas empat hal prinsip-prinsip dalam Indeks Pembangunan Manusia sebagai berikut :

1. Produktivitas

Penduduk harus dimampukan untuk meningkatkan produktivitas dan berpartisipasi penuh dalam proses penciptaan pendapatan dan nafkah. 
2. Pemerataan

Penduduk harus memiliki kesempatan yang sama untuk mendapatkan akses terhadap semua sumber daya ekonomi dan sosial. Semua hambatan yang memperkecil kesempatan untuk memperoleh akses tersebut harus dihapus, sehingga mereka dapat mengambil menfaat dan berpartisipasi dalam kegiatan produktif yang dapat meningkatkan kualitas hidup.

3. Kesinambungan

Akses terhadap sumber daya ekonomi dan sosial harus dipastikan tidak hanya untuk generasi saat ini, tetapi juga generasi yang akan datang. Semua sumber daya fisik, manusia, dan lingkungan harus selalu diperbaharui.

4. Pemberdayaan

Penduduk harus berpartisipasi penuh dalam keputusan dan proses yang akan menentukan (bentuk/arah) kehidupan mereka, serta untuk berpartisipasi dan mengambil manfaat dari proses pembangunan.

\subsection{Kemiskinan}

\subsubsection{Definisi Kemiskinan}

Menurut Badan Pusat Statistik, kemiskinan dipandang sebagai ketidakmampuan dari sisi ekonomi untuk memenuhi kebutuhan dasar makanan dan bukan makanan yang diukur dari sisi pengeluaran.Jadi penduduk miskin adalah penduduk yang memiliki rata-rata pengeluaran perkapita perbulan dibawah garis kemiskinan (BPS, 2015).

\subsubsection{Penyebab Kemiskinan}

Adapun terjadinya kemiskinan di antaranya disebabkan oleh keterbelakangan manusia dan sumber daya alam.Pengelolaan sumber daya alam sangat tergantung kemampuan produktif manusia. Jika penduduknya banyak yang miskin dan berpendidikan rendah maka akan mengakibatkan langkanya keterampilan teknik, pengetahuan, dan aktivitas kewiraswataan yang secara otomatis akan menyebabkan sumber daya alam yang tersedia justru terbengkalai, tidak berkembang, atau bahkan salah guna. Sumber daya alam ini akan mempengaruhi tingkat pertumbuhan ekonomi. Di sisi lain, kurangnya sumber daya alam akan menyebabkan kemiskinan karena sumber daya alam adalah sumber utama kebutuhan hidup manusia. Kemiskinan sumber daya alam merupakan sebab dan sekaligus akibat kemiskinan manusia (Jhingan, 2016).

\subsubsection{Ukuran Kemiskinan}

Todaro dalam (Permana, 2012) melihat kemiskinan dari dua sisi yaitu :

a. Kemiskinan Absolut

Kemiskinan absolut merupakan ketidakmampuan seseorang dengan pendapatan yang diperolehnya untuk mencukupi kebutuhan dasar minimum yang diperlukan untuk hidup setiap hari.Kebutuhan minimum tersebut diterjemahkan dalam ukuran finansial (uang).Nilai minimum tersebut 21 digunakan sebagai batas garis kemiskinan. Garis kemiskinan ditetapkan pada tingkat yang selalu konstan secara riil, sehingga dapat ditelusuri kemajuan yang diperoleh dalam menanggulangi kemiskinan pada level absolut sepanjang waktu.

b. Kemiskinan Relatif

Kemiskinan relatif ditentukan berdasarkan ketidakmampuan untuk mencapai standar kehidupan yang ditetapkan masyarakat setempat sehingga proses 
penentuannya sangat subyektif. Mereka yang berada dibawah standar penilaian tersebut dikategorikan sebagai miskin secara relatif.

\section{METODE PENELITIAN}

\subsection{Jenis Penelitian}

Jenis penelitian yang digunakan adalah Penelitian kuantitatif yaitu metode penelitian yang bersifat sistematis dan menggunakan model-model yang bersifat matematis.

\subsection{Jenis Data dan Sumber Data}

Jenis data dalam penelitian ini merupakan data sekunder yang diperoleh dari Badan Pusat Statistika (BPS) Provinsi Kepulauan Bangka Belitung.Untuk melengkapi data yang diperlukan, maka digunakan data dan informasi yang diperoleh dari hasil penelitian terdahulu, buku, artikel, internet maupun perpustakaan serta publikasipublikasi lain yang relevan.

\subsection{Teknik Analisis Data}

Penelitian ini menggunakan pendekatan kuantitatif dengan metode data panel (pooled data), yaitu gabungan data Time Series dan Cross Section. Pengelolaan data menggunakan software statistik, menarik kesimpulan dan mendapatkan suatu keputusan untuk analisis yang telah dilakukan.

\subsubsection{Common Effect Model (CEM)}

Teknik model regresi data panel dengan mengkombinasikan data time series dan cross section.Data dikombinasi tanpa memperhatikan perbedaan antar waktu dan individu.Model ini bisa saja mengambarkan hubungan yang sebenarnya antara variabel independen dan dependen antar unit cross section. Secara umum model regresi dapat dinyatakan pada persamaan berikut:

$$
Y_{i t}=X_{I t}^{\prime} \beta+U_{i t}+\varepsilon_{i t}
$$

Dimana :

$Y_{i t} \quad$ : unit cross section ke-i untuk periode waktu ke-t

$X_{I t}^{\prime} \beta$ : menunjukkan vektor observasi pada variabel independen berukuran $\mathrm{k} \mathrm{x} 1$

$\alpha_{i}$ : efek group/individu dari unit cross section ke-i yang bernilai konstan sepanjang waktu $t$ atau bahkan berbeda-beda untuk setiap unit cross section ke-i

$U_{i t} \quad$ : error regresi untuk group ke-i untuk periode waktu ke-t.

\subsubsection{Fixed Effect Method (FEM)}

Pendekatan model efek tetap diasumsikan bahwa intersep dan slope dari persamaan regresi dianggap konstan baik antar unit cross section maupun antar unit time series.Jika menggunakan slope konstan tetapi intersep bervariasi untuk setiap individu, maka kita dapat menggunakan variabel dummy perusahaan (unit cross sectional) untuk diamati. Model regresi dapat ditulis sebagai berikut:

$$
Y_{i t}=X_{I t}^{\prime} \beta+c_{i}+d_{t}+\varepsilon_{i t}
$$


Dimana :

$c_{i} \quad$ : konstanta yang bergantung pada unit ke-i, tetapi tidak pada waku t.

$d_{t} \quad$ : konstanta yang bergantung pada waktu t, tetapi tidak pada unit i.

Oleh karena itu penggunaan teknik variabel dummy dalam proses regresi, maka FEM biasa juga disebut Least Square Dummy Variables (LSDV). Teknik variabel dummy bisa digunakan pada unit Cross Section Orunit Time Series.

\subsubsection{Random Effect Model (REM)}

Dalam mengestimasi data panel melalui pendekatan FEM, variabel dummy menunjukkan ketidakpastian model yang digunakan. Untuk mengatasi masalah ini, digunakan variabel residual yang dikenal dengan pendekatan random effect model (REM). Ide dasar dari REM adalah mengasumsikan error bersifat random sehingga dapat diestimasi dengan metode Generalized Least Square (GLS).

$$
\mathrm{Y}=\mathrm{a}+\beta_{1} X_{1}+\beta_{2} X_{2}+\ldots \ldots+\beta_{n} X_{n}+\varepsilon_{i t} .
$$

Dimana:

Y : variabel Kemiskinan

$\mathrm{X}_{1} \quad$ : Indeks Pembangunan Manusia

$\mathrm{X}_{2} \quad$ : Kemiskinan

A : konstanta

b : adalah koefisien regresi pada masing-masing variabel bebas

\subsection{Definisi Oprasional Variabel}

1. Pertumbuhan Ekonomi : Pertumbuhan ekonomi adalah proses perubahan kondisi perekonomian suatu wilayah secara berkesinambungan menuju keadaan yang lebih baik selama periode tertentu. Pertumbuhan ekonomi dapat diartikan juga sebagai proses kenaikan kapasitas produksi suatu perekonomian yang diwujudkan dalam bentuk kenaikan pendapatan wilayah/daerah dalam bentuk persen dengan menggunakan data Laju Pertumbuhan PDRB ADHK.

2. Indeks Pembangunan Manusia (IPM) : IPM menurut BPS merupakan indikator komposit tunggal yang digunakan untuk mengukur pencapaian pembangunan manusia yang telah dilakukan di suatu wilayah. tiga indikator pembangunan manusia yaitu indeks kesehatan,indeks pendidikan dan indeks daya beli. Data yang digunakan adalah data indeks pembangunan manusia di kabupaten/kota Provinsi Kep.Bangka Belitung dinyatakan dalam satuan persen

3. Kemiskinan : Persentase penduduk yang berada dibawah garis kemiskinan.Untuk mengukur kemiskinan, BPS menggunakan konsep kemampuan memenuhi kebutuhan dasar (basic needs approach).

\section{HASIL DAN PEMBAHASAN}

\subsection{Pemilihan Model}

Dalam melakukan analisis data pengaruh Indeks Pembangunan Manusia dan Kemiskinan terhadap Pertumbuhan Ekonomi dengan variabel independennya adalah Indeks Pembangunan Manusia dan Kemiskinan. Pemilihan model dilakukan menggunakan analisis regresi data panel dengan 3 model yaitu common effect model, fixed effect model dan random effect model. Untuk memilih model mana yang tepat antara common effect model dan fixed effect model digunakan uji likelihood atau chow test. Sedangkan untuk memilih fixed effect model dan random effect model 
pengujian yang digunakan adalah melihat Hausman test. Uji LM Test digunakan untuk melihat atau membandingkan common effect model dan random effect model. Kemudian uji penaksiran modelnya tersebut dapat dilihat sebagai berikut :

\subsubsection{Chow Test atau Likelihood}

Tabel 4.1. Chow Test (Common Effect Model Vs Fixed Effect Model)

Redundant Fixed Effects Tests

Test cross-section fixed effects

\begin{tabular}{lccc}
\hline Effects Test & Statistic & d.f. & Prob. \\
\hline Cross-section F & 10.222208 & $(6,47)$ & 0.000 \\
Cross-section Chi-square & 46.763613 & 6 & 0.000 \\
\hline
\end{tabular}

Sumber: Data diolah (2019)

Dalam pengujian Chow Test atau Likelihood digunakan untuk membandingkan common effect model dengan fixed effect model untuk pemilihan model terbaik yang akan digunakan dalam penelitian ini. Hasil pengujian chow test diperoleh probabilitas 0,000 dengan tingkat signifikan sebesar pada $\alpha=5 \%$. Nilai probabilitas $0,000<0,05$ menunjukkan bahwa keputusan model yang digunakan dari hasil uji chow test ini adalah fixed effect model.

\subsubsection{Hausmant Tests}

Tabel 4.2. Hausmant Tests (Random Effect Model Vs Fixed Effect Model)

Correlated Random Effects - Hausman Test

Test cross-section random effects

\begin{tabular}{lccc}
\hline Test Summary & Chi-Sq. Statistic & Chi-Sq. d.f. & Prob. \\
\hline Cross-section random & 17.572580 & 2 & 0.0002 \\
\hline
\end{tabular}

Sumber: Data diolah (2019)

Dalam pengujian Hausmant Tests digunakan untuk membandingkan random effect model dengan fixed effect model untuk pemilihan model terbaik yang akan digunakan dalam penelitian ini.Dari hasil pengujian hausman test didapatkan hasil dengan probabilitas sebesar 0.0002 . Sehingga nilai probabilitas $0,0002>0,05$ artinya model yang digunakan adalah fixed effect model.

\subsection{Pengaruh Indeks Pembangunan Manusia dan Kemiskinan Terhadap Pertumbuhan Ekonomi}

Dari pengujian model yang telah dilakukan maka didapatkan Fixed Effect Model sebagai model terbaik dalam penelitian ini. Berikut adalah hasil yang diperoleh yaitu sebagai berikut:

Tabel 4.3 Hasil Uji Fixed Effect Model

\begin{tabular}{|c|c|c|c|}
\hline Variable & Koefisien & t-test & Prob. \\
\hline $\mathrm{C}$ & 37.82018 & 5.578083 & 0.0000 \\
\hline $\mathrm{X} 1$ & -0.450315 & -4.953491 & 0.0000 \\
\hline $\mathrm{X} 2$ & -0.380009 & -2.405626 & 0.0201 \\
\hline $\mathrm{R}$-squared & 0.567736 & & \\
\hline Adjusted R-squared & 0.494159 & & \\
\hline F-statistic & 7.716228 & & \\
\hline
\end{tabular}


Berdasarkan tabel diatas maka analisis regresi data panel dengan pendekatan Fixed Effect Model diperoleh persamaan sebagai berikut yaitu :

$E C G W=37.82018-0,450315 H M I-0,380009 P V R T+\varepsilon_{i t}$

Dari hasil persamaan Uji statistik di atas, maka diperoleh bahwa variabel indeks pembangunan manusia berpengaruh negatif dan signifikan terhadap tingkat pertumbuhan ekonomi Kabupaten/kota di Provinsi Kepulauan Bangka Belitungdalam kurun waktu 2010-2017. Jika dilihat dari nilai koefisien indeks pembangunan manusia berpengaruh negatif seperti yang dijelaskan oleh nilai koefisiennya sebesar -0,450315 yang artinya jika terdapat kenaikan indeks pembangunan manusia sebesar 1 (persen) maka akan menurunkan tingkat pertumbuhan ekonomi di Kabupaten/Kota di Provinsi Kepulauan Bangka Belitung sebesar 0,450315 atau 45,0315 (persen), serta signifikan dilihat dari nilai probabilitasnya yaitu sebesar $0.0000<0,05$. Hal tersebut menunjukan bahwa adanya kenaikan indeks pembangunan manusia, akan menyebabkan penurunan tingkat pertumbuhan ekonomi di Kabupaten/Kota di Provinsi Kepulauan Bangka Belitung pada kurun waktu 2010-2017.

Untuk indeks pembangunan manusia yang berpengaruh negatif terhadap pertumbuhan ekonomi disebabkan oleh PDRB yang masih relatif rendah pada kurun waktu tahun 2010-2017 dan juga disebabkan oleh PDRB Kabupaten Bangka Tengah yang mengalami penurunan yang cukup signifikan disebabkan oleh berhenti beroperasinya salah satu perusahaan swasta pelebur timah yaitu PT KOBATIN. Penelitian ini sejalan dengan penelitian yang telah dilakukan oleh Moh Muqorrobin dan Ady Soejoto yang berjudul "Pengaruh Indeks Pembangunan Manusia (Ipm) Terhadap Pertumbuhan Ekonomi Provinsi Jawa Timur" yang menyatakan bahwa variabel indeks pembangunan manusia berpengaruh negatif dan signifikan terhadap pertumbuhan ekonomi provinsi Jawa Timur.

Hasil analisis uji statistik, menunjukkan bahwa variabel kemiskinan memiliki pengaruh yang negatif dansignifikan terhadap tingkat pertumbuhan ekonomi Kabupaten/kota di Provinsi Kepulauan Bangka Belitung dalam kurun waktu 2010-2017. Dengan nilai koefisien sebesar-0.380009 yang artinya jika terjadi kenaikan persentase penduduk miskin sebesar 1 (persen) maka akan menurunkan tingkat pertumbuhan ekonomi Kabupaten/Kota di Provinsi Kepulauan Bangka Belitung sebesar0.380009atau 38.0009 (persen), dengan nilai probabilitas $0.0201<\alpha=0,05$ yang berarti berpengaruh signifikan. Hal tersebut menunjukan bahwa adanya kenaikan kemiskinan, akan menyebabkan penurunan tingkat pertumbuhan ekonomi di Kabupaten/Kota di Provinsi Kepulauan Bangka Belitung pada kurun waktu 2010-2017.

Untuk variabel kemiskinan yang berpengaruh negatif dikarenakan sudah mulai meratanya pembangunan yang menyebar disetiap daerah pelosok-pelosok sehingga kemiskinan kian menurun untuk kurun waktu tahun 2010-2017. Penelitian ini juga sejalan dengan penelitian yang telah dilakukan oleh Teguh Anshori yang berjudul "Analisis Pengaruh Tingkat Kemiskinan, Tenaga Kerja dan Desentralisasi Fiskal Terhadap Pertumbuhan Ekonomi di Eks-Karesidenan Surakarta Tahun 2006-2010” yang menyatakan bahwa variabel kemiskinan memiliki pengaruh negatif dan signifikan terhadap PDRB. Variabel jumlah tenaga kerja memiliki pengaruh positif dan tidak signifikan terhadap PDRB.Variabel desentralisasi fiskal yang diproksi dengan rasio antara pendapatan asli daerah (PAD) ditambah bagi hasil pajak dan bukan pajak dengan realisasi pengeluaran total pemerintah menunjukkan pengaruh positif dan signifikan terhadap PDRB di eks-Karesidenan Surakarta tahun 2006-2010. 
Dan diketahui dari hasil Fixd Effect Model bahwa nilai Adjusted R-squared sebesar 0.494159 atau 49 (persen), artinya dari 49 (persen) variabel jumlah tingkat pertumbuhan ekonomi Kabupaten/Kota di Provinsi Kepulauan Bangka Belitung dipengaruhi oleh indeks pembangunan manusia dan persentase jumlah penduduk miskin. Sisanya 51 (persen) dijelaskan oleh variabel lain diluar model yang tidak diteliti.

\section{KESIMPULAN DAN SARAN}

\subsection{KESIMPULAN}

Berdasarkan hasil analisis yang mengunakan metode analisis regresi panel dengan pendekatan Fixed Effect Model dapat disimpulkan bahwa indeks pembangunan manusia berpengaruh negatif dan signifikan terhadap Pertumbuhan Ekonomi Kabupaten/Kota di Provinsi Kepulauan Bangka Belitung. Indeks Pembangunan Manusia berpengaruh negatif seperti yang dijelaskan oleh nilai koefisiennya sebesar -0,450315 yang artinya jika terdapat kenaikan indeks pembangunan manusia sebesar 1 (persen) maka akan menurunkan tingkat pertumbuhan ekonomi di Kabupaten/Kota di Provinsi Kepulauan Bangka Belitung sebesar 0,450315 atau 45,0315 (persen), serta signifikan dilihat dari nilai probabilitasnya yaitu sebesar $0.0000<0,05$. Sedangkan variabel kemiskinan berpengaruh negative dan signifikan terhadap tingkat pertumbuhan ekonomi di Kabupaten/Kota di Provinsi Kepulauan Bangka Belitung tahun 2010-2017. Dengan nilai koefisien sebesar-0.380009 yang artinya jika terjadi kenaikan persentase penduduk miskin sebesar 1 (persen) maka akan menurunkan tingkat pertumbuhan ekonomi Kabupaten/Kota di Provinsi Kepulauan Bangka Belitung sebesar 0.380009atau 38.0009 (persen), dengan nilai probabilitas $0.0201<\alpha=0,05$ yang berarti berpengaruh signifikan. Dan diketahui dari hasil Fixd Effect Model bahwa nilai Adjusted R-squared sebesar 0.494159 atau 49 (persen), artinya dari 49 (persen) variabel jumlah tingkat pertumbuhan ekonomi Kabupaten/Kota di Provinsi Kepulauan Bangka Belitung dipengaruhi oleh indeks pembangunan manusia dan persentase jumlah penduduk miskin. Sisanya 51 (persen) dijelaskan oleh variabel lain diluar model yang tidak diteliti.

\subsection{SARAN}

Berdasarkan hasil dari kesimpulan diatas, adapun saran yang diajukan adalah sebagai berikut :

1. Pemerintah mulai memperhatikan kualitas masyarakat, pendidikan, kesehatan serta perekonomian masyarakat Kabupaten atau Kota di Provinsi Kepulauan Bangka Belitung sehingga angka indeks pembangunan manusia lebih meningkat dan pada akhirnya akan meningkatkan pertumbuhan ekonomi.

2. Pemerintah ikut serta dalam pengentasan kemiskinan seperti membuka lapangan pekerjaan serta meratakan pembangunan di setiap daerah bukan hanya kota saja, sehingga dapat meminimalkan pengangguran di Kabupaten atau Kota di Provinsi Kepulauan Bangka Belitung sehingga dapat mempengaruhipertumbuhan ekonomi agar dapat tetap stabil.

3. Pada penelitian selanjutnya penulis menyarankan untuk menambahkan variabel lain yang tidak diteliti pada penelitian ini sehingga akan mendapatkan infomasi yang lebih baik.

\section{UCAPAN TERIMA KASIH}

Puji Syukur penulis panjatkan kepada Tuhan Yang Maha Esa, sehingga dapat menyelesaikan penelitian ini dengan diberikan kemudahan dan tepat waktu. Oleh karena itu, 
penulis ingin mengucapkan terima kasih kepaa pihak yang telah membantu dalam penyusunan dan dukungannya kepada penulis :

1. Orang tua dan kakak yang selalu memberikan motivasi dan semangat dalam menyelesaikan penelitian ini.

2. Ibu Dr. Devi Valeriani, S.E.,M.Si, selaku Ketua Jurusan Program Studi Ekonomi

3. Ibu Aning Kesuma Putri, S.E.,M.Si, selaku Dosen Pembimbing dalam penelitian ini

4. Bapak Aja Nasrun, S.ST, M.Sc selaku Dosen Pembimbing Lapangan dalam penelitian ini

5. Seluruh teman-teman yang sudah membantu dalam proses pembuatan penelitian ini.

\section{REFERENSI}

Anshori, Teguh. (2013). Analisis Pengaruh Tingkat Kemiskinan, Tenaga Kerja dan Desentralisasi Fiskal Terhadap Pertumbuhan Ekonomi Di Eks-Karesidenan Surakarta Tahun 2006-2010. Surakarta. Diakses 9 September 2019. http://eprints.ums.ac.id/25783/26/NASKAH_PUBLIKASI.pdf

Arifin, Imamul \& Gina, Hadi. (2009). Membuka Cakrawala Ekonomi. Jakarta: Salemba Empat.

Arsyad, Lincolin. (2010). Ekonomi Pembangunan. Yogyakarta: STIM YKPN

Asya Yandi Dea Kristina, 2017. Pengaruh Pendapatan Asli Daerah, Indeks Pembangunan Manusia dan Tenaga Kerja Terhadap Produk Domestik Regional Bruto (38 Kabupaten/Kota di Provinsi Jawa Timur Tahun 2011-2016), Jurnal Ilmu Ekonomi Vol 1 Jilid 2/2017 Hal. 176 - 188

Badan Pusat Statistik. (2010). Kepulauan Bangka Belitung Dalam Angka 2010-2017. https://babel.bps.go.id/

Badrudin, Rudy. (2012). Ekonomika Otonomi Daerah. Yogyakarta : UPP STIM YKPN

De Moraes, Márcia Azanha Ferraz Dias. (2015). Mírian Rumenos Piedade Bacchi. Accelerated growth of the sugarcane, sugar, and ethanol sectors in Brazil (20002008): Effects on municipal gross domesticproduct per capita in the south-central region.Carlos Eduardo Caldarelli. Biomass and Bioenergy, 91, pp.116- 125.

Jhingan. M.L. (2016). Ekonomi Pembangunan dan Perencanaan. Jakarta: Rajawali

Maharani, Kurnia dan Sri Isnowati. (2014). Kajian Investasi, Pengeluaran Pemerintah ,Tenaga Kerja dan Keterbukaan Ekonomi Terhadap Pertumbuhan Ekonomi di Provinsi Jawa Tengah. Jurnal Bisnis dan Ekonomi (JBE): Vol.21, No.1. ISSN: 14123126.

Masriah, dkk. (2011). Pembangunan Ekonomi Berwawasan Lingkungan.Malang : UM Press,.

Melliana, A. \& Zain, I. (2013). Analisis Statistika Faktor yang Mempengaruhi Indeks Pembangunan Manusia di Kabupaten/Kota Provinsi Jawa Timur dengan Menggunakan Regresi Panel. Jurnal Sains dan Seni Pomits.2 (2), D237-D242.

Moh. Arif Novriansya. (2009). Pengaruh Pengangguran dan Kemiskinan Terhadap Pertumbuhan Ekonomi di Provinsi Gorontalo". Vol.1,No.1. ISSN: 2614-5170. 9 September 2019 https://www.researchgate.net/publication/328166327_Pengaruh_Pengangguran_dan _Kemiskinan_Terhadap_Pertumbuhan_Ekonomi_di_Provinsi_Gorontalo

Moh Muqorrobin.2017. Pengaruh Indeks Pembangunan Manusia (IPM) Terhadap Pertumbuhan Ekonomi Provinsi Jawa Timur, Jurnal Pendidikan Ekonomi.Vol.5.No.3. $\begin{array}{llll}\text { Diakses } & 9 & \text { September } & 2019\end{array}$ https://jurnalmahasiswa.unesa.ac.id/index.php/jupe/article/view/20602

Permana,Yoga, Anggit. (2012). Analisis Pengaruh PDRB, Pengangguran, Pendidikan, dan Kesehatan terhadap Kemiskinan di Jawa Tengah tahun 2004-2009, Jurnal Ekonomi, $\begin{array}{lllll}\text { Vol.1, } & \text { No.1. } & \text { Diakses } & 9 & \text { September }\end{array}$ 
https://ejournal3.undip.ac.id/index.php/jme/article/view/128

Prawoto, Nano. (2009) Memahami Kemiskinan dan Strategi Penanggulangannya. Jurnal Ekonomi dan Studi Pembangunan, 9.1,: 56-68. Diakses 9 September 2019. Https://scholar.google.co.id.

Puti, Andiny. (2017). Analisis Pertumbuhan Ekonomi dan Kemiskinan Terhadap Ketimpangan Di Provinsi Aceh, Jurnal Penelitian Ekonomi Akuntansi, Vol. 1, No. 2. Diakses 9 September 2019 : https://ejurnalunsam.id/index.php/jensi/article/view/412

Rakhmawati Rusmarinda. (2016). Pengaruh Indeks Pembangunan Manusia (IPM), Tenaga Kerja, dan Pendidikan TerhadapPertumbuhan Ekonomi Di Provinsi Jawa Tengah. $\begin{array}{lllll}\text { Jawa } & \text { Tengah. } & \text { Diakses } & 9 & \text { September }\end{array}$ http://eprints.ums.ac.id/41810/1/NASKAH\%20PUBLIKASI.pdf

Retno Ely Kusuma. (2011). Pengaruh Pendidikan Dan Kemiskinan Terhadap Pertumbuhan Ekonomi Di Indonesia. Issue:2004 hal,1-20. Diakses 9 September 2019: https://jurnalmahasiswa.unesa.ac.id/index.php/jupe/article/view/3579/6182

Shinegi, Diomi. 2013. Pengertian dan Penjelasan IPM (Indeks Pembangunan Manusia)

$\begin{array}{lllll}\text { Diakses } & \text { pada } & 9 & \text { September } & 2019 \\ \end{array}$ http://diomishinegi.blogspot.com/2014/02/pengertian-dan-penjelasan-ipmindeks.html

Sukirno, Sadono. (2011). Makro Ekonomi Teori Pengantar Edisi Ketiga. Rajawali Pers, Jakarta

Untoro, Joko. (2010). Ekonomi Makro. Jakarta: Kawah Media

Wijayanto Ravi Dwi, (2010), "Analisis Pengaruh PDRB, Pendidikan dan Pengangguran Terhadap Kemiskinan di Kabupaten/Kota di Jawa Tengah Tahun 2005-2008”, Semarang. $\quad$ Diakses $\quad 9 \quad$ September http://eprints.undip.ac.id/23008/1/SKRIPSI.PDF

Wongdesmiwati. (2009). Pertumbuhan Ekonomi dan Pengentasan Kemiskinan di Indonesia, diakses 9 September 2019 melalui : http://wongdesmiwati.wordpress.com/2009/10/24/ pertumbuhan-ekonomi-dan-pengentasan-kemiskinan-di-indonesia-analisisekonometri. 